\title{
VALIDATION OF A PREDICTIVE MODEL DESCRIBING GROWTH OF SALMONELLA IN ENTERAL FEEDS
}

\author{
Roberta Ribeiro Silva ${ }^{1}$; Célia Alencar Moraes ${ }^{2}$; Josefina Bessan ${ }^{3}$; Maria Cristina Dantas Vanetti ${ }^{2 *}$ \\ ${ }^{1}$ Departamento de Nutrição, Universidade de Alfenas, Alfenas, MG, Brasil $;{ }^{2}$ Departamento de Microbiologia, Universidade \\ Federal de Viçosa, Viçosa, MG, Brasil; ${ }^{3}$ Departamento de Nutrição, Universidade Federal de Viçosa, Viçosa, MG, Brasil
}

Submitted: March 26, 2008; Returned to authors for corrections: July 24, 2008; Approved: February 25, 2009.

\begin{abstract}
The growth of Salmonella enterica subs. enterica sorovar Typhimurium at $25^{\circ} \mathrm{C}$ was monitored in industrialized and hospital formulated enteral feeds and the results were used to validate the mathematical model of Salmonella growth presented by the Pathogen Modeling Program (PMP) 7.0 (USDA-USA). The generation time of Salmonella in enteral feeds ranged from 21 to $34.8 \mathrm{~min}$ and, the maximum growth rate ( $\mu \mathrm{max})$ varied from 1.28 to $1.95 \mathrm{~h}^{-1}$, resulting in a population increase from 5 to $6 \log _{10}$ cycles within 14 to $24 \mathrm{~h}$ incubation. Growth was faster in the hospital formulated feed containing vegetables and eggs. The growth kinetic's parameters as lag phase; $\mu$ max and maximum population density (MPD) were similar to those predicted by the PMP 7.0, with exception of lag phase in enteral diet at $\mathrm{pH}$ 6.3. The results of this study validated the PMP 7.0 model for describe Salmonella growth in enteral feeds and demonstrates the appropriateness of use such model to determine the pathogen behavior in a wide range of storage conditions in this food.
\end{abstract}

Key words: predictive microbiology, Salmonella growth, enteral diets.

\section{INTRODUCTION}

Transmission of pathogenic or potentially pathogenic bacteria by foods is particularly important when occurring in hospitalized individuals, often debilitated by severe diseases, inadequate nutrition or as a consequence of chemotherapeutic treatments. Therefore, meal preparation in hospital kitchen environment must observed rigorous practices of sanitaryhygienic conditions in order to ensure safety foods $(4,6)$.

Among the feeds consumed by hospitalized patients, the enteral formulas are considered of high risk, due to the high nutrient content as well as the administration system used, since in some cases, the drip goes beyond the acid barrier of the stomach, transporting the food directly to the duodenum and jejunum. In this environmental, with neutral $\mathrm{pH}$, contaminating microorganisms can proliferate and colonize the intestine, whose resident microbiota may have been significantly diminished by the systemic use of antibiotics therapy. Contamination of enteral feed frequently occurs during preparation, dilution or even during the administration procedures $(5,6)$.
Enteral nutrition solutions may be contaminated by bacteria such as Pseudomonas, Enterobacter and Klebsiella $(8,11,22,26)$, which are not considered potentially pathogenic agents for healthy adults but are confirmed and documented as infectious and diarrhea agents in immunedeppressed, malnourished elderly patients (9). Numbers of bacteria from a range up to $10^{7} \mathrm{CFU} / \mathrm{mL}$ has been found in enteral feeds $(4,19,22,23,27)$ and seem to result from preparation, transportation and non-refrigerated storage conditions. The greatest risk, however, occurs when enteral feed was contaminated with pathogenic microorganisms. Gill and Gill (14) reported a case of $S$. enteritidis infection associated with enteral feeds prepared in hospital kitchens and suggested that feed contamination may occur from human sources, raw egg surfaces or cross - contamination in the kitchen environment. Between 1999 and 2000, eight cases of Salmonella infection were reported at the Hospital das Clínicas in São Paulo, Brazil. All the patients aged 19 to 79, who presented diarrhea, had been administered enteral feed with lyophilized albumin and the presence of Salmonella was confirmed in their feces and blood (21).

*Corresponding Author. Mailing address: Department of Microbiology, Federal University of Viçosa 36570-000 Viçosa, MG Brazil. Tel.: +55-31 3899-2954; Fax: +55-313899-2753. E-mail: mvanetti@ufv.br 
Conservation of enteral feeds under adequate temperature conditions is essential to maintain their quality. However, the administration of enteral feeds generally occurs at room temperature and the time these feeds remain exposed may allow an adequate condition for growth of contaminating microorganisms $(5,7,20)$. Bastow et al. (5) found in hospitalformulated feeds counts ranging from $10^{2}$ to $10^{3} \mathrm{CFU} / \mathrm{mL}$ of aerobe mesophiles after meal preparation and from $10^{8}$ to $10^{10}$ $\mathrm{CFU} / \mathrm{mL}$ after $24 \mathrm{~h}$ of exposure at room temperatures, between $21^{\circ} \mathrm{C}$ and $24^{\circ} \mathrm{C}$. Industrialized enteral diets ready-to-feed present little risk of contamination (16), being safer for patient health.

Mathematical models that predict the growth of bacterial pathogens such as Salmonella, are useful tools for the food industry. Most of the predictive models for the growth of bacterial pathogens were derived from kinetics data obtained in culture medium used in the laboratory under standardized conditions. The US Department of Agriculture (USDA) Agricultural Research Service's Pathogen Modeling Program (PMP, version 7.0) is a predictive model program based on the growth models in culture mediums available on the website (http://www.arserrc.gov/mfs/ pathogen.htm). Applying predictive models, such as the PMP, in a food system, will help validate data resulting from simulations using specific foods.

This study aimed to evaluate Salmonella growth in different enteral feeds under temperatures generally adopted during feed storage and administration. The experimental data obtained were used to validate PMP model of Salmonella growth.

\section{MATERIALS AND METHODS}

\section{Bacteria}

Salmonella enterica subs. enterica sorovar Typhimurium, of human origin, isolated and identified at the Ezequiel Dias Foundation (FUNED, Belo Horizonte, MG, Brazil) was used. A stock culture of $S$. Typhimurium was kept in semi solid agar Brain Heart Infusion-BHI added of $20 \%$ glycerol solution at $80 \%$, and stored at $-80^{\circ} \mathrm{C}$.

\section{Enteral feeds preparation and analysis}

$S$. Typhimurium growth was monitored in the commercially made powdered feeds vanilla flavored Soya Diet ${ }^{\circledR}$ (Support) and Ensure ${ }^{\circledR}$ (Abbott) and in hospital formulated-feed. The industrialized feeds were prepared according to the manufacturers' recommendations, with the powder being aseptically weighed and diluted in sterilized water. The $\mathrm{pH}$ of the Soya Diet ${ }^{\circledR}$ was corrected with $\mathrm{HCl} 0.1 \mathrm{~N}$ for values of approximately 6.1 . Such correction was necessary so that the feed would present a $\mathrm{pH}$ value within the limits established by the modeling program selected. Non-industrialized vegetablebased enteral feed (NIEF-V), enriched with in natura egg was prepared in the kitchen of a hospital in Ponte Nova, MG, Brazil, and aseptically collected in sterilized containers, immediately following its preparation.

The feeds used in this study were evaluated for $\mathrm{pH}$, water activity $\left(\mathrm{a}_{\mathrm{w}}\right)$ and osmolarity. The $\mathrm{pH}$ was determined on potentiometer (Digimed, São Paulo, Brazil); $\mathrm{a}_{\mathrm{w}}$ was determined using the automatic analyzer Aqua Lab Model CX-2 (Decagon, Washington, USA). Feed osmolarity was evaluated by the ITR Digital Electronic Cryoscope.

\section{Salmonella growth in enteral feeds}

After activation in $\mathrm{BHI}$ solution at $37^{\circ} \mathrm{C}$ for $24 \mathrm{~h}$, the culture was centrifuged and the collected cells were resuspended in saline solution and used to inoculate the enteral feeds, with approximately, $10^{3} \mathrm{CFU} / \mathrm{mL}$. After inoculation, feed portions of $100 \mathrm{~mL}$ were distributed in flasks grouped into two batches: one was kept at $4^{\circ} \mathrm{C}$ in refrigerator for period of $6 \mathrm{~h}$ and then transferred to $25^{\circ} \mathrm{C}$. The other batch was incubated at $25^{\circ} \mathrm{C}$ for $12 \mathrm{~h}$. At every $2 \mathrm{~h}$ interval of incubation at $25^{\circ} \mathrm{C}$, one flask was removed from the incubator to determine the number of viable Salmonella cells on agar MacConkey (Merck, Darmstadt, Germany). Plating was done in duplicate, using the automatic Spiral Plater (Autoplate, 4000- Spiral Biotech Inc., Bethesda, $\mathrm{MD})$.

The experiment was repeated three times, with duplicate in each repetition. The data mean was used to validate the mathematical model for predicting Salmonella growth presented in the PMP 7.0.

\section{Validation of the PMP 7.0 model for predicting Salmonella growth in enteral feeds}

Validation of the bacterial growth model proposed by the USDA Pathogen Modeling Program PMP 7.0 was performed using the experimental data obtained on Salmonella growth in the evaluated feeds. Based on information published by Gibson et al. (13), the data generated for the construction of mathematical models describing the growth of Salmonella presented in the PMP 7.0 led to the acquisition of parameters referring to microbial growth according to the Gompertz model:

$$
\mathrm{L}(\mathrm{t})=\mathrm{A}+\mathrm{C} \exp \{-\exp [-\mathrm{B}(\mathrm{t}-\mathrm{M})]\}
$$

where: $\mathrm{L}(\mathrm{t})=$ decimal logarithm of viable cell count at time $\mathrm{t}, \mathrm{A}$ $=$ number of initial cells, $\mathrm{B}=$ Relative growth rate, $\mathrm{C}=5.97, \mathrm{M}=$ Time where specific growth rate is maximum.

The parameters were derived in: $\mathrm{TG}=\log _{10} 2 \mathrm{x}$ and $/ \mathrm{B} \times \mathrm{C}$ and

$$
\operatorname{Lag}=\mathrm{M}-1 / \mathrm{B}
$$

Specific maximum growth rate $(\mu)$ of $S$. enteritidis in the feeds used in this study was determined by selecting the points obtained experimentally and that corresponded to the exponential growth phase. A linear regression was then 
performed and the straight line equation was obtained where the inclination was equal to $\mu$. Generation time ( 1 ) was calculated as a function of $\mu$, where $l=\ln 2 / \mu$. The lag phase $(\lambda)$ was estimated by determining the intersection of the straight line obtained by linear regression of the points relative to the exponential growth with the value of the initial number of cells. The resulting growth kinetics compared with predictions from the USDA PMP 7.0 model.

Temperature of hospital refrigerator used to storage enteral diets were determined as well as the environmental temperatures, at which the diets were generally administrate.

\section{RESULTS}

The feeds used in this study presented $\mathrm{pH}$ between 6.8 and $7.8, \mathrm{a}_{\mathrm{w}}$ between 0.990 and $0.995 \pm 0.03$ and osmolarity varying from 64.51 to $415.05 \mathrm{mOsmol} / \mathrm{L}$ (Table 1).

Salmonella did not grow in the feeds kept under refrigeration at $4^{\circ} \mathrm{C}$, for a period of $6 \mathrm{~h}$. However, this earlier maintenance under refrigeration resulted in reduction of the lag phase time (1) at $25^{\circ} \mathrm{C}$ and generation time of Salmonella in the enteral feeds (Table 2). Feeds maintained at $25^{\circ} \mathrm{C}$ resulted in an increase of the initial population of Salmonella of $10^{3} \mathrm{CFU} / \mathrm{mL}$ to $10^{8}$ to $10^{9} \mathrm{CFU} / \mathrm{mL}$, into 18 to $24 \mathrm{~h}$ (Figs. 1-3). This growth was detected after a lag phase of a maximum of $2.8 \mathrm{~h}$ (Table 2 ).

The values of mean lag phase time and mean generation time (1) obtained following the analysis of the experimental data of Salmonella growth in the enteral feedings were compared to

Table 1. Mean $\mathrm{pH}$, water activity $\left(\mathrm{a}_{\mathrm{w}}\right)$ and osmolarity values of industrialized and non-industrialized enteral feeds.

\begin{tabular}{lccc}
\hline Enteral Feeds & $\mathrm{pH}$ & $\mathrm{a}_{\mathrm{w}}$ & $\mathrm{mOsmol} / \mathrm{L}$ \\
\hline Soya Diet & 7.79 & 0.991 & 179.03 \\
Ensure & 6.75 & 0.990 & 415.05 \\
NIEF-V & 6.83 & 0.992 & 193.55 \\
\hline
\end{tabular}

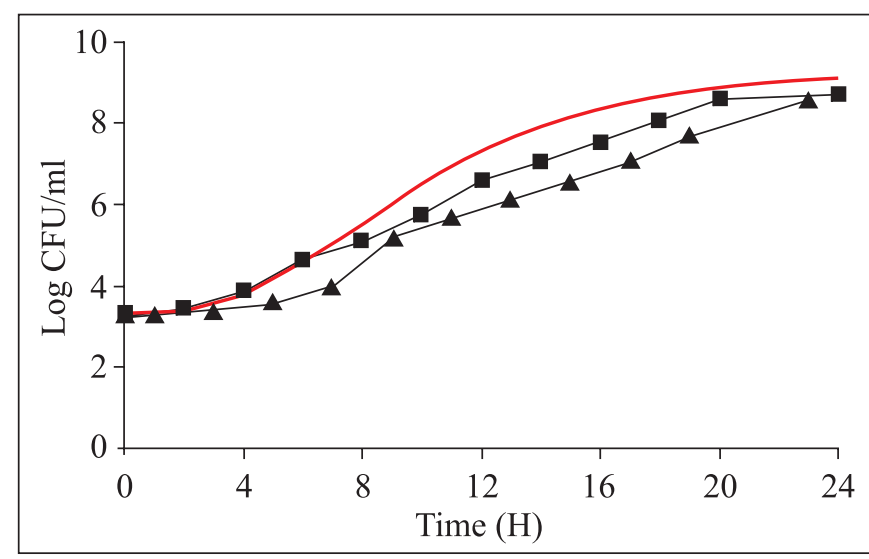

Figure 1. Growth of Salmonella predicted by PMP 7.0 (-) and obtained with the experimental data of Salmonella Typhimurium growth in industrialized enteral feed (Soya Diet) at $25^{\circ} \mathrm{C}$ and stored at $4^{\circ} \mathrm{C}$ for $6 \mathrm{~h}$ and, then incubated at $25^{\circ} \mathrm{C}(\boldsymbol{\Delta})$.

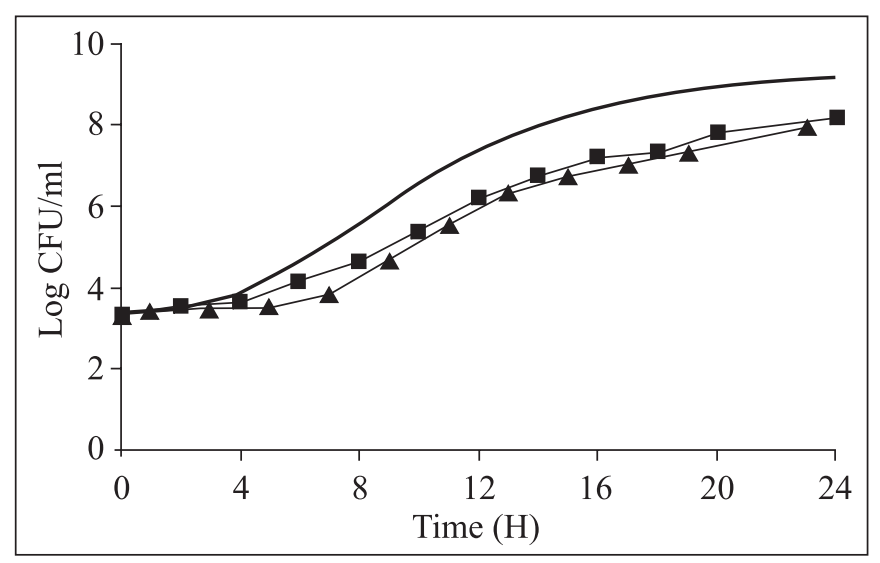

Figure 2. Growth of Salmonella predicted by PMP 7.0 (-) and obtained with the experimental data of Salmonella Typhimurium growth in industrialized enteral feed (Ensure) at $25^{\circ} \mathrm{C}(\boldsymbol{\square})$ and stored at $4^{\circ} \mathrm{C}$ for $6 \mathrm{~h}$ and, then incubated at $25^{\circ} \mathrm{C}(\boldsymbol{\Delta})$.

Table 2. Estimates of growth rate, lag time and maximum population density of Salmonella Typhimurium inoculated in enteral feeds and prediction calculation by the Pathogen Modeling Program (PMP 7.0).

\begin{tabular}{lccccccccc}
\hline & \multicolumn{3}{c}{$\begin{array}{c}\text { Lag phase } \\
(\mathrm{h})\end{array}$} & \multicolumn{3}{c}{$\begin{array}{c}\text { Growth rate } \\
\left(\mathrm{h}^{-1}\right)\end{array}$} & \multicolumn{3}{c}{$\begin{array}{c}\text { maximum population density } \\
\left(\log _{10} \mathrm{CFU} / \mathrm{mL}\right)\end{array}$} \\
\cline { 2 - 10 } Enteral Feed & \multicolumn{2}{c}{ Measured } & Predicted & \multicolumn{2}{c}{ Measured } & Predicted & \multicolumn{2}{c}{ Measured } & Predicted \\
\cline { 2 - 10 } & $255^{\circ} \mathrm{C}^{*}$ & $4 / 25^{\circ} \mathrm{C}^{\mathrm{H}}$ & & $25^{\circ} \mathrm{C}^{*}$ & $4 / 25^{\circ} \mathrm{C}^{\mathrm{H}}$ & & $25^{\circ} \mathrm{C}^{*}$ & $4 / 25^{\circ} \mathrm{C}^{\mathrm{H}}$ & \\
\hline Soya Diet & 1.79 & 0.92 & $3.3(2.7-4.0)$ & 1.38 & 1.35 & $0.6(0.5-0.6)$ & 8.68 & 8.57 & $9.1(7.5-10.5)$ \\
Ensure & 2.80 & 0.68 & $3.5(2.6-4.6)$ & 1.28 & 1.73 & $0.6(0.5-0.7)$ & 8.15 & 7.93 & $9.5(7.8-11.6)$ \\
NIEF-V & 2.06 & 0.47 & $3.7(2.6-5.2)$ & 1.33 & 1.95 & $0.6(0.5-0.7)$ & 8.95 & 8.86 & $9.5(7.4-12.2)$ \\
\hline
\end{tabular}

* Feeds incubated at $25^{\circ} \mathrm{C}$; ${ }^{\mathrm{H}} \mathrm{Feeds}$ stored at $4^{\circ} \mathrm{C}$ for $6 \mathrm{~h}$ and, then incubated at $25^{\circ} \mathrm{C}$. 
the values predicted by the program PMP 7.0, considering the respective conditions of $\mathrm{pH}$, incubation temperature, $\mathrm{a}_{\mathrm{w}}$ values and initial inoculum. Only the $\lambda$ experimental data of the Soya Diet $^{\circledR}$ with the $\mathrm{pH}$ fitted to 6.3 were not within the range of values predicted in the PMP 7.0 models, at $25^{\circ} \mathrm{C}$. However, the 1 in the three diets evaluated were within the interval predicted both the ones incubated at $25^{\circ} \mathrm{C}$, as well as after $6 \mathrm{~h}$ at $4^{\circ} \mathrm{C}$ and later at $25^{\circ} \mathrm{C}$.

Refrigerators temperatures where NIEF-V was stored varied from 11 and $18^{\circ} \mathrm{C}$ and environmental temperatures of hospital rooms were, on average, $26.5^{\circ} \mathrm{C}$.

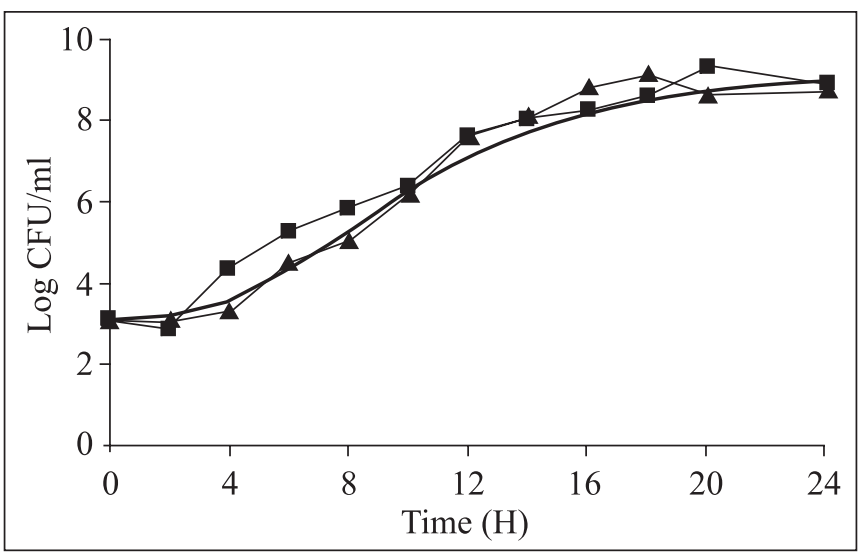

Figure 3. Growth of Salmonella predicted by PMP $7.0(-)$ and obtained with the experimental data of Salmonella Typhimurium growth in non-industrialized enteral feed (NIEF-V) at $25^{\circ} \mathrm{C}(\boldsymbol{\square})$ and stored at $4^{\circ} \mathrm{C}$ for $6 \mathrm{~h}$ and, then incubated at $25^{\circ} \mathrm{C}(\boldsymbol{\Delta})$.

\section{DISCUSSION}

Enteral feeds generally present $\mathrm{pH}$ values near neutrality, favoring the growth of the great majority of contaminating bacteria, including pathogens as Salmonella. The lowering $\mathrm{pH}$ in the enteral feeds may contribute to reduce or inhibit bacterial growth (25). Besides the $\mathrm{pH}, \mathrm{a}_{\mathrm{w}}$ and osmolarity of the enteral feeds are high and do not prevent the growth of contaminating agents. Anderton (1) verified that bacteria that contaminate enteral feeds grow under high osmolarity as well as in isotonic solutions. The only factor that may act as a barrier to reduce bacterial activity in enteral feeds prepared in hospital kitchens is refrigeration. At $4^{\circ} \mathrm{C}$ growth of Salmonella and of most of the contaminating microorganisms is inhibited. Storing enteral feeds at $4^{\circ} \mathrm{C}$ for $24 \mathrm{~h}$ did not allow the growth of $S$. enteritidis (28) and of contaminating bacteria such as Enterobacter cloacae, Pseudomonas aeruginosa, Klebsiella aerogenes, Staphylococcus aureus and E. coli (1). Nevertheless, in enteral feeds kept at $25^{\circ} \mathrm{C}$ Salmonella reached high populations within a short time interval, this result being indicative of the risk these feeds as substrates also for the growth of other conventional or opportunistic pathogens. Anderton and Aidoo (3) verified an increase between 3 and $10 \log _{10}$ cycles in the population of $E$. coli and $K$. aerogenes in enteral feeds prepared by handlers with hands previously contaminated with $10^{3} \mathrm{CFU}$, after $24 \mathrm{~h}$ maintenance at $37^{\circ} \mathrm{C}$. These authors found counts lower than $10^{2} \mathrm{CFU} / \mathrm{mL}$, after $4 \mathrm{~h}$, at $37^{\circ} \mathrm{C}$ in diets with non-detectable levels of contamination at the initial stages of administration. In debilitated patients, the presence of pathogens, even in low numbers, may result in health risks. Infectious dose of Salmonella can be smaller in patients with diminished gastric acidity, children, elderly, and immunedeppressed individuals (18). Patients that fed enteral feeds would be among the most susceptible, since the natural barriers of the organism are altered, compromising immunity and stomach acidity.

One way to evaluate the performance of mathematical models could be comparing product direct inoculation data. The results obtained during lag phase, generation time and maximum Salmonella population density in enteral feeds allow to confirm that the predictive model established by the PMP 7.0 is satisfactorily fitted to describe $S$. Typhimurium growth in these feeds and confirm the observation of Gibson et al. (13) that there is a good correlation between the predicted Salmonella growth and those obtained from different feeds.

The growth rates observed for Salmonella in this study were high when compared to others found in the literature surveyed and reinforce our concern with the intrinsic conditions of enteral feeds favoring bacterial growth. Davey and Daughtry (10) reported a value of $0.335 \mathrm{~h}^{-1}$ for the growth rate of Salmonella in $0.7 \%$ of $\mathrm{NaCl}$ and $\mathrm{pH}$ of 6.77 . This growth rate was 0.509 when the salt concentration was increased to $1.33 \%$, and the $\mathrm{pH}$ altered to 6.13. Oscar (24) found a Salmonella growth rate in BHI broth of $0.250 \pm 0.008$ at $20^{\circ} \mathrm{C}, \mathrm{pH}$ of 6.3 and $0.610 \pm 0.014$ at $30^{\circ} \mathrm{C}, \mathrm{pH}$ of 7.4. Estimated means of the exponential growth rate of Salmonella clinical isolates and feeds at temperatures of 19 and $37^{\circ} \mathrm{C}$ were $0.26 \log _{10} \mathrm{~h}^{-1}$ and $1.26 \log _{10} \mathrm{~h}^{-1}$, respectively (17).

However, in other foods such as chorizos, the mathematical model used in the PMP 7.0 cannot make a precise and safe prediction of the kinetic parameters for Salmonella (15). One must bear in mind that such factors, as contaminating microbiota and nutrient distribution and access to nutrients, interfere with bacterial growth in food. Therefore, further researches are needed to determine the kinetics of real microorganism growth in different foods and conditions (17).

Considering that the Salmonella predictive growth model proposed by the PMP 7.0 was validated for the three enteral feeds, a prediction of the growth of this pathogen was performed adopting ambient and refrigerator temperatures obtained at a hospital unit aiming to simulate storage and administration conditions. If the Soya $\operatorname{Diet}^{\mathbb{R}}$ with the $\mathrm{pH}$ fitted to 6.23 , the 
Ensure $^{\circledR}$ and NIEF-V were stored at the temperatures of 11 and $18^{\circ} \mathrm{C}$ detected in the hospital refrigerators and had been contaminated with only $1 \mathrm{CFU} / \mathrm{mL}$ of Salmonella, after $24 \mathrm{~h}$ storage, at $11^{\circ} \mathrm{C}$, the population could be maintained in $1 \mathrm{CFU} /$ $\mathrm{mL}$. However, at $18^{\circ} \mathrm{C}$, it would be, on an average, $1.6 \times 10^{3} \mathrm{CFU} /$ $\mathrm{mL}$. One must point out that this final population, although presenting a low number of viable cells of Salmonella, may pose a high risk for immune deficiency and weak individuals.

If enteral feeds were maintained at room temperature, recorded in one of the feeding rooms of, that was, on average, $26.5^{\circ} \mathrm{C}$ and contamination with only $1 \mathrm{CFU} / \mathrm{mL}$, it would result in a population of $2.3 \mathrm{CFU} / \mathrm{mL}$ after the period of $4 \mathrm{~h}$ and of 3.2 $\mathrm{x} 10^{1} \mathrm{CFU} / \mathrm{mL}$ after $6 \mathrm{~h}$ feeding. One should stress the observation that the main problem with enteral feeds is the fact that they are conserved and administered at hospital aisle temperatures for long periods of time (12). Due to the risk of microbial multiplication in enteral feeds kept at room temperatures, Anderton (2) proposed a maximum time of $4 \mathrm{~h}$ of exposure at room temperature for enteral formulas.

Bastow et al. (5) confirmed the ease with which enteral feeds prepared in hospital kitchens can become contaminated, when mixing ingredients, by pathogen organisms that may display rapid growth, when the feeds are kept at room temperature for many hours. Those authors concluded that the administration of these feeds may result in patients being contaminated with a number of bacteria sufficient to promote colonization, resulting in cross-infections in those patients whose natural resistance may be compromised.

Quality monitoring during all the feed preparation and administration phases for this particular group of individuals must be recommended as a standard practice. The diets prepared in a hospital environment must be adequately transported and be immediately transferred to the refrigerator at adequate temperatures and sufficiently low to inhibit the growth contaminants.

The evaluation of the performance of the microbial growth predictive models is generally conducted by comparing the predictions with the microbial growth kinetics data published or obtained experimentally in different feeds. Verification of PMP 7.0 performance to predict Salmonella growth in enteral feeds is important since it suggests that this program is a useful tool to assess the risk of this pathogen's growth under different $\mathrm{pH}$, $\mathrm{a}_{\mathrm{w}}$, and storage temperatures and feed administration conditions.

\section{RESUMO}

\section{Validação de um modelo preditivo para descrever o crescimento de Salmonella em dietas enterais}

O crescimento de Salmonella enterica subs. enterica sorovar Typhimurium a $25^{\circ} \mathrm{C}$ foi determinado em dietas enterais industrializadas e formuladas em hospital e os resultados obtidos foram usados para validar um modelo matemático de crescimento de Salmonella apresentado no Programa de Modelagem de Patógenos (PMP), versão 7,0 (USDA-EUA). O tempo de geração de Salmonella em dietas enterais variou de 21 a 34,8 min e a velocidade específica máxima de crescimento ( $\mu$ max) foi de 1,28 a $1,95 \mathrm{~h}^{-1}$, resultando em aumento de 5 a 6 ciclos logarítimos em um período de 14 a 24 h de incubação. $\mathrm{O}$ crescimento foi mais rápido na dieta formulada em hospital contendo vegetais e ovos. Os parâmetros cinéticos como fase lag, $\mu$ max e densidade populacional máxima (MDP) foram similares aqueles previstos no PMP 7.0, com exceção da fase lag em dietas enteral com $\mathrm{pH}$ 6,3. Os resultados deste estudo validaram o modelo do PMP 7,0 para descrever o crescimento de Salmonella em dietas enterais e demonstraram a propriedade desse modelo para determinar o comportamento do patógeno em uma variedade de condições nesse tipo de alimento.

Palavras-chave: microbiologia predictiva, Salmonella, dietas enterais.

\section{REFERENCES}

1. Anderton, A. (1985). Growth of bacteria in enteral feeding solutions. J. Med. Microbiol. 20 (1), 63-68.

2. Anderton, A. (1986). Microbiological quality of products used in enteral feeds. J. Hosp. Infect. 7 (1), 68-73.

3. Anderton, A.; Aidoo, K.E. (1988). The effect of handling procedures on microbial contamination of enteral feeds. J. Hosp. Infect. 11 (4), 364-372.

4. Arias, M.L.; Monge, R.; Antillon, F.; Chavez, C. (1999). Microbiological contamination of enteral feeding solutions used in Costa Rican hospitals. Arch. Latinoam. Nutr. 49 (4), 363-366.

5. Bastow, M.D.; Greaves, P.; Allison, S.P. (1982). Microbial contamination of enteral feeds. Hum. Nutr. Appl. Nutr., 36A (3), 213-217

6. Carvalho, L.R.M.; Morais, B.T.; Amaral, F.D.; Sigulem, M.D. (2000) Hazard analysis and critical control point system approach in the evaluation of environmental and procedural sources of contamination of enteral feeding in three hospitals. J. Parent. Ent. Nutr. 24 (5), 296-303.

7. Carvalho, M.L.R.; Morais, T.B.; Sigulem, D.M. (1999). Pontos críticos no controle da manipulação de dietas enterais no Município de São Paulo. Nutr. Clín. 14 (3), 145-155.

8. Casewell, M.W. (1977). The epidemiology of Klebsiella aerogenes in an intensive care unit. Thesis (MD) - University of London.

9. Chaaya, A.P.M.B.; Sacramento, A.D.L.; Vilar, J.M.; Ruffier, C.P. (1997). Suporte nuticional enteral em ambiente domiciliar: via e método de administração e complicações após 1 ano de prestação de serviços. Rev. Bras. Nutr. Clin. 12 (1), 21-26.

10. Davey, K.P.; Daughtry, B.J. (1995). Validation of a model for predicting the combined effect of three environmental factors on both exponential and lag phases of bacterial growth: temperature, salt concentration and pH. Food Res. Int. 28 (3), 233-237.

11. Fagerman, K.E. (1992). Limiting bacterial contamination of enteral nutrition solutions: 6-year history with reduction of contamination at two institutions. Nutr. Clin. Prac. 7 (1), 31-36.

12. Gibbs, J. (1983). Bacterial contamination of nasogastric feeds. Nurs. Times 79 (7), 41-47.

13. Gibson, A.M.; Bratchell, N.; Roberts, T.A. (1988). Predicting microbial growth: growth responses of Salmonellae in a laboratory medium as 
affected by $\mathrm{pH}$, sodium chloride and storage temperature. Int. J. Food Microbiol. 6( 2),155-178.

14. Gill, K.J.; Gill, P. (1971). Contaminated enteral feeds. Br. Med. J. 282, 1971.

15. Hajmeer, M.; Basheer, I.; Cliver, D.O. (2006). Survival curves of Listeria monocytogenes in chorizos modeled with artificial neural networks. Food Microbiol. 23 (6), 561-570.

16. Hsu, T.C.; Chen, N.R.; Sullivan, M.M.; Kohn-Keeth, C.L.; Meints, A.S.; Shott, S.; Comer, G.M. (2000). Effect of high temperature on contamination and physic stability of one-liter ready-to-hang enteral delivery systems. Nutr. 28 (3), 904-906.

17. Juneja, V.K.; Marks, H.M.; Huang, L. (2003). Growth and heat resistance kinetic variation among various isolates of Salmonella and its application to risk assessment. Risk Anal. 23 (1), 199-213.

18. Kruri-Bulos, N.A.; Khalaf, M.A.; Shehabi, A.; Shami, K. (1994). Foodhandler associated Salmonella outbreak in a university hospital despite routine surveillance cultures of kitchen employees. Infect. Contr. Hosp. Epidemiol. 15, 311-314.

19. Lima, A.R.C.; Barros, L.M.; Rosa, M.S.; Cardonha, A.M.S.; Dantas, M.A.M. (2005). Avaliação microbiológica de dietas enterais manipuladas em um hospital. Acta Cirúrg. Brasil. 20 (1), 27-30.

20. Maki, D.G. (1976). Growth properties of microorganisms in infusion fluid and methods of detection. In: Phillips, Meers, P.D., D'arcy, P.F. Microbiological hazards of infusion therapy, Lancaster: MTP.

21. Matsuoka, D.M.; Costa, S.F., Mangini; C., Almeida, G.M.D.; Bento, C.N.; Heijden, I.M.V.; Soares, R.E.; Gobara, S.; Tavora, L.G.F.; Levina,
A.S. (2004). A nosocomial outbreak of Salmonella enteritidis associated with lyophilized enteral nutrition. J. Hosp. Infect. 58, 122-127.

22. Okuma, T.M.D.; Nakamura, M.R.N.; Totake, H.; Fukunaga, Y.MD. (2000). Microbial contamination of enteral feeding formulas and diarrhea. Nutr. 16 (9), 719-722.

23. Oliveira, M.H.; Bonelli, R.; Aidoo, K.E.; Batizta, C.R. (2000). Microbiological quality of reconstituted enteral formulations used in hospitals. Nutr. 16 (9), 729-733.

24. Oscar, T.P. (1999). Response surface models for effects of temperature, $\mathrm{pH}$, and previous growth $\mathrm{pH}$ on growth kinetics of Salmonella typhimurium in Brain Heart Infusion Broth. J. Food Prot. 62 (2), 106-111.

25. Ovesen, L.; Hansen, L.; Allingstrup, E.W.; Adsersen, L.; Langballe, M.; Frøkjær, K.S. (1991). Bacterial contamination and growth in two defined formula diets of different pH. Clin. Nutri. 10, 114119.

26. Pinto, U.M.; Cardoso, R.R.; Vanetti, M.C.D. (2004). Detection of Listeria, Salmonella and Klebsiella in a hospital food service. Rev. Nutr. 17 (3), 319-326.

27. Pottecher, B.; Goetc, M.L.; Jacquemaire, M.A.; Reeb, E.; Lavillaureix, J. (1979). Enterocolites infectieuses chez des malades de reanimaton alimentes par sond nasogastrique. Ann. Anesth. 20 (6-7), 595-602.

28. Stanek, G.; Hirschl, A.; Lochs, H.; Egger, T.P. (1983). Growth of various bacteria and yeasts in a peptide and elemental diet. J. Hosp. Infect. 4 (1), 51-56. 